\title{
Social Studies Teachers' Homework Practices in Oman
}

\author{
Saif Al-Maamari ${ }^{1}$ \\ ${ }^{1}$ Curriculum and Instruction Department, Sultan Qaboos University, Oman \\ Correspondence: Saif Al-Maamari. E-mail: saifn2@hotmail.com
}

Received: June 2, $2020 \quad$ Accepted: June 10, $2020 \quad$ Online Published: June 29, 2020

doi:10.5539/ass.v16n7p146 URL: https://doi.org/10.5539/ass.v16n7p146

\begin{abstract}
This study aims at discovering the homework practices of ten social studies teachers in basic education schools of the second cycle (grades 5-10) in Muscat governorate, Oman. The sample comprised of (10) teacher' planning books ( 5 male teachers and 5 female teachers) distributed in ten schools. The researchers designed a check list for analyzing the planning books of teachers consists of four domains: the types of homework tasks, the levels of knowledge of homework according to Bloom's taxonomy, the resources required to answer homework tasks, and the nature of working on homework. Findings of the study showed that social studies teachers assigned conventional homeworks, which might not be consistent with new goals of social studies in Oman.
\end{abstract}

Keywords: Homework practices, social studies in Oman, Education in Oman, Social studies teachers.

\section{Introduction}

Homework has been used in the educational systems to help the students to meet academic goals. Although classroom teaching focuses on developing knowledge and skills, homework has played a substantial role as supplemental learning opportunities for students (İflazoğlu \& Hong, 2012). At present there is a growing interest in exploring the practices and effectiveness of homework as it is regarded as important component in learning process (Cooper \& Valentine, 2001; Marzano \& Pickering, 2007; Hagger, Sultan, Hardcastle, \& Chatzisarantis, 2015). Homework is defined as the set of school tasks that are assigned by teachers for students to complete outside of school hours (Cooper, Steenbergen-Hu, \& Dent, 2012). Teachers' views and practices remain noticeably absent from this growing homework debates (Trautwein, Niggli, Schnyder, \& Ludke, 2009; Bang, 2012). Deveci and Yiğit (2015) pointed out that homework assignment is not affected by the educational change as the teachers believes in its benefits to the students from pre-school education to higher education. Homework assignment, in Oman, is employed by teachers to achieve a set of educational goals. Yet, we have limited knowledge about the homework practices which are employed by social studies education. Therefore, the current study attempts to fill this research gap in literature by investigating the homework practices that are employed by Omani social studies teachers.

In many educational systems homework is an essential practice. The literature shows disagreement about the impact of homework on student performance. The proponents of homework highlighted the role of homework on enhancing students' achievement and attitudes (Epstein, Simon, \& Salinas, 1997; Cooper, Nye, \& Grathouse, 1998; Cooper \& Valentine, 2001). Especially at the middle and secondary school levels (Xu, 2010). Cooper, Nye, and Grathouse (1998). Revealed a positive relation between doing homework and students' achievement. Epstein, Simon, Salinas (1997) demonstrated that homework improved students' attitudes, writing and literacy outcomes. By contrast, there were various opponents of homework as it, from their perspective, influence the student learning negatively (e.g Kralovec \& Buell, 2000; Bennett \& Kalish, 2006).

The literature shows that teachers' believe that homework helps to achieve different purposes. Van Voorhis (2004) argues that homework enhances students' participation in their learning. Yet, it was found that good practice of homework is not limited to planning shorter assignment and limiting their number (Cooper, 2001). According to Epstein and Voorhis (2001), various types of homework is important to match students' different abilities. In addition, Patton (1994) stresses on explaining homework and having students begin it in class. Xu (2010) uncovered in his study the variables that influence students' purposes for doing homework which include student and family characteristics, Family homework help, teacher feedback and homework interest. The literature showed that homework should be assigned to students in all educational stages to achieve some academic goals. Yet, some experts argued that homework for primary education should directed to develop non-academic goals 
such as developing study habits and time management skills. In this respect, Dixon (2007) mentioned that Cooper believed in assigning children homework that suited to their development and home situation whereas younger students must be given short homework that does not involve too much effort and time.

\section{Purpose of the Study}

Although there is a growing research activities in the field of social studies in Oman (Author, 2009; Al-Rabani, 2009; Al-Malki, 2013; Al-Hamdi, 2013; Al-Sarmi, 2012), the homework practices in this field are still not investigated nationally and internationally as most of the pervious literature focuses on studying teachers' purpose for assigning homework (Xu, 2010; Trautwein et al., 2009). Thus, this study is original and timely especially at the moment when many calls for evaluating Omani educational system are emerged. It hops that the results generated from this study will provide policy-makers with some insight into some aspects of homework practices. The main focus of the current study is to discover the homework practices of ten social studies teachers in Oman. The study attempts to answer the following questions:

1- What kind of homework tasks were assigned by the social studies teachers?

2- What is the alignment of the cognitive domain levels of the homework items that each teacher assigned to his students as it related to Bloom's Taxonomy?

3- What are the resources required to complete the homework tasks?

4- What are the methods of completing the homework tasks?

\section{Methodology}

\section{Participants}

This study involved a sample of all social studies teachers in basic education schools of the second cycle (grades 5-10) in Muscat governorate. This sample comprised of (10) teacher' planning books (5 male teachers and 5 female teachers) distributed in ten schools.

\section{Instrumentation}

To explore the homework practices in Omani schools, an analysis checklist was designed including five parts: demographic data of teacher, they kinds of homework (answering questions, writing a report, conducting an interview, hearing a broadcast or TV programs, drawing maps or graphs, collecting samples, preparing for a school broadcasting, doing a project, answering a mathematical exercise, and kayaking picture for a phenomena); the homework levels of knowledge (knowledge, comprehension, application, analysis, synthesis, and evaluation); the resources of doing homework (textbook, internet, Atlas, media, computer technology); and the nature of conducting homework (individual, small group, and large group).

The analysis checklist items were developed from our experience in social studies and from related literature (Cooper, Steenbergen-Hu, \& Dent, 2012; Xu, 2010; Trautwein et al., 2009). A panel of educators with specialties in social studies and research methods reviewed the analysis checklist. Based on their recommendations, modifications we made to the analysis checklist. It was pilot tested with a sample of "two planning books" and modified accordingly. Data were collected from the teachers' lesson planning notebooks of fall semester of 2018. Statistical analyses included descriptive statistics such as percentages.

\section{Results}

This section includes demographic characteristics of teachers and their homework practices as reported in their lesson planning notebooks.

\section{Demographics}

Table 1 shows some demographics information about Social studies teachers who agreed to participate in the current study.

\begin{tabular}{cccc}
\hline Teachers & Gender & Specialization & Level of experience \\
\hline 1 & M & History & 15 \\
2 & M & History & 9 \\
3 & M & Geography & 13 \\
4 & M & History & 8 \\
5 & M & Geography & 10 \\
6 & F & Geography & 15 \\
\hline
\end{tabular}




\begin{tabular}{cccc}
\hline 7 & F & History & 16 \\
8 & F & Geography & 8 \\
9 & F & Geography & 9 \\
10 & F & History & 14 \\
\hline
\end{tabular}

As indicated in Table 1, the percentage of males $(50 \%)$ and females $(50 \%)$. They are equally distributed to history and geography but all of them teaching social studies regard less of their major of study. The level of experience of the study sample range from eight to (16) years of experience.

\section{The kinds of homework}

The second part of the tool focused on the kinds of homework that teachers assigned to their students. Despite the nature of social studies that focus on the current events, teachers' practices appear to set rather a conventional approach in the homework tasks they assigned to the students. As shown in Table 2, there is tendency to follow traditional activities such as answering questions, drawing maps or graphs, and writing a report. Yet, they gave a low emphasize on assigning an unconventional homework that require students to take picture the phenomena, doing project, and solving a mathematical exercise. The last tasks that received little attention from the teachers that link students to trace the geographical and history also emphasized on direct students to watch TV programs, conducting interview with people who experienced the event and collecting sample from the environment. These practices might restrict achieving the goals of social studies in Oman.

Table 2. Types of homework task that teachers assigned to their students

\begin{tabular}{|c|c|c|c|c|c|c|c|c|c|c|c|c|}
\hline \multirow{2}{*}{ Items } & \multicolumn{10}{|c|}{ Planning books code } & \multirow{2}{*}{$\mathrm{F}$} & \multirow{2}{*}{$\%$} \\
\hline & 1 & 2 & 3 & 4 & 5 & 6 & 7 & 8 & 9 & 10 & & \\
\hline Answering questions & 9 & 9 & 15 & 13 & 10 & 14 & 13 & 13 & 12 & 11 & 119 & 59.5 \\
\hline Drawing maps or graphs & 4 & 2 & 1 & 4 & 5 & 2 & 3 & 4 & 4 & 5 & 34 & 17 \\
\hline Writing a report & 2 & 4 & 3 & 2 & 1 & 0 & 2 & 1 & 2 & 2 & 19 & 9.5 \\
\hline Taking pictures for a phenomena & 1 & 2 & 0 & 1 & 2 & 1 & 0 & 0 & 1 & 1 & 9 & 4.5 \\
\hline Doing a project & 2 & 0 & 0 & 0 & 1 & 1 & 1 & 1 & 0 & 1 & 7 & 3.5 \\
\hline Answering a mathematical exercise & 2 & 0 & 0 & 0 & 1 & 0 & 1 & 0 & 1 & 0 & 5 & 2.5 \\
\hline $\begin{array}{c}\text { Hearing a broadcast or TV programs, drawing maps } \\
\text { or graphs }\end{array}$ & 0 & 2 & 0 & 0 & 0 & 1 & 0 & 0 & 0 & 0 & 3 & 1.5 \\
\hline Conducting an interview & 0 & 1 & 1 & 0 & 0 & 1 & 0 & 0 & 0 & 0 & 3 & 1.5 \\
\hline Collecting samples & 0 & 0 & 0 & 0 & 0 & 0 & 0 & 1 & 0 & 0 & 1 & 0.5 \\
\hline Total & 20 & 20 & 20 & 20 & 20 & 20 & 20 & 20 & 20 & 20 & 20 & 100 \\
\hline
\end{tabular}

\section{Homework levels of knowledge}

As shown in Table 3, the homework tasks focus on the lower thinking level of Bloom's taxonomy. The rate of comprehension was (37,5\%), following by application (25.5\%), and then become knowledge (21.5). In contrast, the higher order thinking is receiving low consideration with "analysis' level got (14.5\%), following by "synthesis" that rated (1\%). Finally, Teachers assigned no homework task to develop the students' ability to "evaluate". The results confirm the findings from the other study that find social studies focus on rout learning in Oman (Al-Hammami, 1999; Al-Ryami, 2002; Al-Skatit, 2002) and beyond (Barone, 2002; Fairbrother, 2004; Akar, 2006).

Table 3. Homework levels of knowledge

\begin{tabular}{|c|c|c|c|c|c|c|c|c|c|c|c|c|}
\hline \multirow{2}{*}{ Items } & \multicolumn{10}{|c|}{ Planning books code } & \multirow{2}{*}{$\mathrm{F}$} & \multirow{2}{*}{$\%$} \\
\hline & 1 & 2 & 3 & 4 & 5 & 6 & 7 & 8 & 9 & 10 & & \\
\hline Knowledge & 2 & 3 & 6 & 5 & 4 & 6 & 2 & 6 & 2 & 7 & 43 & 21.5 \\
\hline Comprehension & 6 & 8 & 9 & 9 & 6 & 9 & 9 & 8 & 7 & 4 & 75 & 37.5 \\
\hline Application & 7 & 6 & 2 & 4 & 7 & 3 & 3 & 6 & 6 & 7 & 51 & 25.5 \\
\hline Analysis & 5 & 3 & 3 & 2 & 3 & 2 & 4 & 0 & 5 & 2 & 29 & 14.5 \\
\hline Synthesis & 0 & 0 & 0 & 0 & 0 & 0 & 2 & 0 & 0 & 0 & 2 & 1 \\
\hline Evaluation & 0 & 0 & 0 & 0 & 0 & 0 & 0 & 0 & 0 & 0 & 0 & 0 \\
\hline Total & 20 & 20 & 20 & 20 & 20 & 20 & 20 & 20 & 20 & 20 & 200 & 100 \\
\hline
\end{tabular}




\section{Required resources needs for students to complete the homework}

The third part of the analysis check list deals with the required resources needed to complete the homework tasks. As indicated in Table 4, 53.5\% of tasks required students to use "textbook" to complete it while only $4.5 \%$ require them to use the "media" to answer them. These results highlight the authority of "textbook' in teaching social studies where teachers not attempt to link students with new development of the historical, geographical, and civic events and phenomena.

Table 4. Required resources needs for students to complete the homework

\begin{tabular}{|c|c|c|c|c|c|c|c|c|c|c|c|c|}
\hline \multirow{2}{*}{ Items } & \multicolumn{10}{|c|}{ Planning books code } & \multirow{2}{*}{$\mathrm{F}$} & \multirow{2}{*}{$\%$} \\
\hline & 1 & 2 & 3 & 4 & 5 & 6 & 7 & 8 & 9 & 10 & & \\
\hline Textbook & 9 & 7 & 10 & 7 & 9 & 13 & 10 & 15 & 14 & 13 & 107 & 53.5 \\
\hline Resource center & 4 & 4 & 6 & 5 & 3 & 1 & 6 & 3 & 1 & 2 & 35 & 17.5 \\
\hline Internet & 6 & 5 & 3 & 5 & 4 & 3 & 2 & 2 & 4 & 1 & 35 & 17.5 \\
\hline Atlas & 1 & 1 & 0 & 1 & 4 & 1 & 2 & 0 & 1 & 3 & 14 & 7 \\
\hline The Media & 0 & 3 & 1 & 2 & 0 & 2 & 0 & 0 & 0 & 1 & 9 & 4.5 \\
\hline Total & 20 & 20 & 20 & 20 & 20 & 20 & 20 & 20 & 20 & 20 & 200 & 100 \\
\hline
\end{tabular}

\section{Level of work (Individual, in small group) require to complete the homework}

The fourth part of the analysis check list deals with the nature of completing the homework tasks. As indicated in Table $5,78 \%$ of tasks required students to it "individually" while only $13.5 \%$ and $8.5 \%$ require them to complete it in "small groups" and "large group" respectively. These results are in consistent with the nature of homework as it put by Cooper, Steenbergen-Hu, and Dent (2012).

Table 5. Level of work (Individual, in small group, large groups) require to complete the homework

\begin{tabular}{|c|c|c|c|c|c|c|c|c|c|c|c|c|}
\hline \multirow{2}{*}{ Items } & \multicolumn{10}{|c|}{ Planning books code } & \multirow{2}{*}{$\mathrm{F}$} & \multirow{2}{*}{$\%$} \\
\hline & 1 & 2 & 3 & 4 & 5 & 6 & 7 & 8 & 9 & 10 & & \\
\hline Individual & 14 & 16 & 18 & 17 & 16 & 18 & 7 & 16 & 17 & 17 & 156 & 78 \\
\hline Small groups & 3 & 3 & 2 & 2 & 3 & 1 & 8 & 3 & 1 & 1 & 27 & 13.5 \\
\hline Large groups & 3 & 1 & 0 & 1 & 1 & 1 & 5 & 1 & 2 & 2 & 17 & 8.5 \\
\hline Total & 20 & 20 & 20 & 20 & 20 & 20 & 20 & 20 & 20 & 20 & 200 & 100 \\
\hline
\end{tabular}

\section{Discussion}

The purpose of this study was to explore some practices of homework among social studies teachers in basic education schools in Oman. Particularly, the study explored the types of homework tasks, the levels of knowledge of homework according to Bloom's taxonomy, the resources required to answer homework tasks, and the nature of working on homework. Findings of the study showed that social studies teachers assigned conventional homework, which might not be consistent with new goals of social studies in Oman which put more stress on linking students with the current issues. Clearly, this finding reflects important pedagogic issues that limit the ability of social studies to improve the negative attitudes towards subject and to link it with students life (Al-Gharibi, 2008). This lack of interest in the subject influence students' attitudes and homework might be one tool to increase students' interest on the subject.

Although social studies teachers should focus on designing homework that help to achieve different purposes and to meet different level of knowledge (Van Voorhis, 2004), it seems that there is much emphasis on conventional assignments (e.g., answering questions, drawing maps or graphs, writing report). As Fawzy (2012, p.2) noticed, teachers sometimes use homework as "a routine to provide students with drills on important activities". Among the levels that received less emphasis include analysis, synthesis and evaluation. It is important that higher order thinking should be a major focus of social studies. As the Su's (1990) pointed out that although teachers stated that they valued higher order thinking they did not implement it in their classroom. Thus, social studies teachers require to direct their homework assignments to focus on higher order thinking to counter the transmission mode and rote memorization approach that related to social studies (Foster \& Padgett, 1999).

In examining teachers' practices on the resources that students needs to do their homework, the most widely resource was textbooks while the media received less important to complete homework task albeit its provide 
student with up-to-date information about social studies phenomena. As with Al-Nofli's (2013) results, the most commonly used teaching methods by social studies teachers were those methods that adopt student-centered strategies. Clearly, this finding not supports efforts made by the Ministry of Education to shift away from traditional methods to progressive methods that expand students' horizon by study the topics from different resources (Ministry of Education, 2006).

One of the striking findings of this study was that teachers attempt to build a team work to complete homework by assigned tasks that requires work in small and large groups. The majority of teachers (78\%) still focus on assigning individual homework task (see Table 5). In fact, this approach follow the recommendation of most literature to individualized homework (Kralovec \& Buell, 2000; Bennett \& Kalish, 2006). One major element of the last educational reform that focus on enhance the spirit of working in a team (Ministry of Education, 2012). It is worth supporting by policy and training as teachers less likely to enhance the cooperative tasks of homework without supporting from the schools and the parent.

\section{Conclusion}

The present study offered insights into some aspects of homework practices in Oman, especially in Social studies. The data demonstrate the social studies teachers give high consideration to homework in their "planning books". Yet, their practices still conventional as they assigned homework that lead students to rout learning instead of helping them to widen their thinking abilities. Therefore, there are some issues that needs to be tackled in order to make homeworks more effective to improve students' attitudes towards social studies. First, sitting a policy for homework is of important in order to enlighten teachers' practices. Second, teachers require some training to development their homework practice. In previous study, social studies teachers reported that they offering very limited opportunity for participate in professional development programme (Al-Maamari, Al-Nofli, \& Al-Gharibi, 2014). According to Farkas, Johnson and Duffett (1999), training is the main issue that teachers complained about most and Omani teachers are not exceptional. Third, more research about homework is required to explore how this complicated issue affect students learning. Specifically, future research should be directed to investigate social studies perspectives about homework and how they deal with some practices of homework such as correction and feedback as these very important skills to make homework meaningful for students.

\section{References}

Akar, B. (2006). Teacher reflections on the challenges of teaching citizenship education in Lebanon: A qualitative pilot study. Reflection in Education, 2(2), 48-63.

Al-Gharibi, Z. M., (2008). Attitudes related to social studies with young adolescents in the Sultanate of Oman (Unpublished Med thesis). University of Glasgow, United Kingdom. Retrieved from http://theses.gla.ac.uk/568/01/2008Al-Gharibimsc(r).pdf

Al-Hamdi, M. (2013). The level of applying historical thinking skills in teaching history curricula in post-basic education schools in the Sultanate of Oman (Unpublished Med thesis) [In Arabic], Sultan Qaboos University, Oman.

Al-Hammami, H. (1999). Education for the 21st century general education reform in the Sultanate of Oman: Motives, nature and strategies of implementation (Unpublished thesis, PhD). University of Birmingham. UK.

Al-Maaamri, S. N. (2009). Citizenship education in Initial teacher education in the Sultanate of Oman: An exploratory study of the perceptions of student teachers of social studies and their tutors (Unpublished $\mathrm{PhD}$ thesis). University of Glasgow, United Kingdom. Retrieved from http://theses.gla.ac.uk/1081/01/2009saifphd.pdf

Al-Maamari, S.; Al-Nofli, M., \& Al-Gharibi, Z. (2014). The state of Social Studies in Basic Education Schools in Oman. Asian Social Science, 10(7), 213-220.

Al-Malki, L. (2013). The employment degree of critical thinking skills by social studies teachers in the pot-basic education in the Sultanate of Oman (Unpublished Med thesis) [In Arabic], Sultan Qaboos University, Oman.

Al-Nofli, M. A. (2013). The state of geography in basic education schools in Muscat, Oman. International Research in Geographical and Environmental Education, (2), 109-119.

Al-Rabani, A. H. (2009). Global Issues in Oman social studies textbooks (grades 3-12) [In Arabic]. Journal of Educational \& Psychological Studies, 3(1), 1-23.

Al-Ryami, A. (2002). An evaluation study of some historical research skills necessary for the History 
Department Students at the Colleges of Education in Oman (Unpublished dissertation MEd, in Arabic), Faculty of Education, Sultan Qaboos University, Oman.

Al-Sarmi, B. A. (2012). The reality of Education for global citizenship in the Sultanate of Oman from social studies teachers' perspectives (Unpublished Med thesis) [In Arabic], Sultan Qaboos University, Oman.

Al-Skatit, S. (2002). Evaluating tasks included in the Omani social studies textbooks of the first Cycle of Basic education (Unpublished Dissertation MEd, in Arabic), Faculty of Education, Sultan Qaboos University, Oman.

Bang, H. (2012). Promising homework practices: Teachers perspectives on making homework work for newcomer immigrant students. The high School Journal, 95, 3-31.

Barone, T. (2002). Civic education and citizenship in Malaysian education. Paper presented at the annual meeting of the American Educational Research Association, New Orleans, April 1-5, ERIC Ed 465672.

Bennett, S. \& Kalish, N. (2006). The case against homework: How homework is hurting our children and what we can do about it. New York NY: Three River Press.

Cooper, H., \& Valentine, J. (2001). Using research to answer practical questions about homework. Educational Psychologist, 36(3), 143-153.

Cooper, H., Lindsay, J. J., Nye, B., \& Greathouse, S. (1998). Relationships among attitudes about homework, amount of homework assigned and completed, and student achievement. Journal of Educational Psychology, 90(1), 70-83. https://doi.org/10.1037/0022-0663.90.1.70

Cooper, H., Steenbergen-Hu, S., \& Dent, A. L. (2012). Homework. In K. R. Harris, S. Graham, T. Urdan, A. G. Bus, S. Major, \& H. L. Swanson (Eds.), APA handbooks in psychology. APA educational psychology handbook, Vol. 3. Application to learning and teaching (pp. 475-495). American Psychological Association. https://doi.org/10.1037/13275-019

Deveci, İ., \& Yiğit, N. (2015). Homework assignment preference scale for science courses: A validity and reliability study. International Journal of Education, 7(2), 193-214.

Dixon, N. (2007). Homework for the $21^{\text {st }}$ century. Queensland Parliamentary Library, Australia.

Epstein, J., \& Van Voorhis, (2001). More than minutes teachers' roles in designing homework. Educational Psychologist, 36(3), 181-193. https://doi.org/10.1207/S15326985EP3603_4

Epstein, J., Simon, B. S., \& Salinas, K. (1997). Involving parents in Homework in the middle grades. Baltimore, MD: Johns Hopkins University, Center for Evaluation, Development and Research.

Fairbrother, G. (2004). Patriotic education in a Chinese Middle School. In W. Lee., D. Grossman., K. Kennedy., \& G. Fairbrother (Eds.), Citizenship education in Asia and the Pacific concepts and issues, CERC Studies in Comparative Education 14. The Netherlands: Kluwer Academic Publishers Group.

Farkas, S., Johnson, J., \& Duffett, A. (1999). Playing their parts: Parents and teachers talk about parental involvement in public schools. New York NY: Public Agenda.

Fawzy, N. (2012). School teachers' perspectives on homework: A comparative study (Unpublished Med thesis), The American University in Cairo, Egypt.

Foster, S., \& Padgett, C. (1999). Authentic historical inquiry in the social studies classroom. The Clearing House, 72(6), 357-363.

Hagger, M., Sultan, S., Hardcastle, S., \& Chatzisarantis, N. (2015). Perceived autonomy support and autonomous motivation toward mathematics activities in educational and out-of-school contexts is related to mathematics homework behavior and attainment. Contemporary Educational Psychology, (41), 111-123.

İflazoğlu, A., \& Hong, E. (2012). Relationships of Homework Motivation and Preferences to Homework Achievement and Attitudes in Turkish Students. Journal of Research in Childhood Education, 16(1), 57-72, https://doi.org/10.1080/02568543.2011.632066

Kralovec, E., \& Buell, J. (2000). The end of homework: How homework disrupts families, overburdens children, and limits learning. Boston MA: Beacon Press.

Marzano, R., \& Pickering, D. (2007). Special topic: The case for and against homework. Educational leadership, 64(60), 74-79.

Ministry of Education, Oman. (2006). From access to success: Education for all [EFA] in the Sultanate of Oman 
1970-2005. Muscat: Author.

Ministry of Education, Oman. (2012). Education in Oman: The drive for quality. Muscat: Author.

Su, Z. (1990). Exploring the moral socialization of teacher candidates. Oxford Review of Education, 16(3), 367-391.

Trautwein, U., Niggli, A., Schnyder, I., \& Ludke, O. (2009). Between-teacher differences in homework assignments and the development of students' homework effort, homework emotions and achievement. Journal of Educational Psychology, 101(1), 167-18.

Van Voorhis, F. L. (2004). Reflecting on the homework ritual: Assignments and designs. Theory into Practice, 43(3), 205-212.

$\mathrm{Xu}$, J. (2010). Predicting homework time management at the secondary school level: A multilevel analysis. leaning and Individual Differences, 20, 34-39.

\section{Copyrights}

Copyright for this article is retained by the author(s), with first publication rights granted to the journal.

This is an open-access article distributed under the terms and conditions of the Creative Commons Attribution license (http://creativecommons.org/licenses/by/4.0/). 